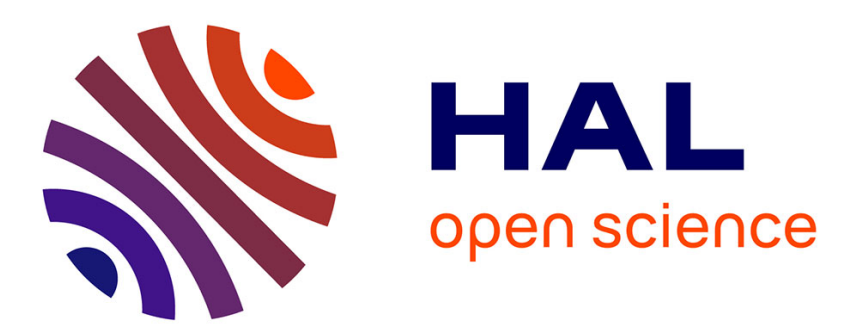

\title{
Stereotactic biopsies of brainstem lesions: dilemma on the best trajectory
}

Bertrand Mathon, Henri Malaizé, Aymeric Amelot

\section{To cite this version:}

Bertrand Mathon, Henri Malaizé, Aymeric Amelot. Stereotactic biopsies of brainstem lesions: dilemma on the best trajectory. Acta Neurochirurgica, 2021, 10.1007/s00701-021-04924-x . hal-03278617

\section{HAL Id: hal-03278617 \\ https://hal.sorbonne-universite.fr/hal-03278617}

Submitted on 5 Jul 2021

HAL is a multi-disciplinary open access archive for the deposit and dissemination of scientific research documents, whether they are published or not. The documents may come from teaching and research institutions in France or abroad, or from public or private research centers.
L'archive ouverte pluridisciplinaire HAL, est destinée au dépôt et à la diffusion de documents scientifiques de niveau recherche, publiés ou non, émanant des établissements d'enseignement et de recherche français ou étrangers, des laboratoires publics ou privés. 
Stereotactic biopsies of brainstem lesions: dilemma on the best trajectory

Bertrand MATHON, MD ${ }^{1,2}$; Henri MALAIZE, MD'; Aymeric AMELOT MD, PhD ${ }^{1,3}$. On behalf of the PSL BRAIN-BIOPSY STUDY GROUP.

1. Department of Neurosurgery, APHP - Sorbonne University, La Pitié-Salpêtrière Hospital, Paris, France.

2. INSERM U 1127, CNRS UMR 7225, Sorbonne University, Paris Brain Institute, ICM, Paris, France.

3. Department of Neurosurgery, Bretonneau Hospital, Tours, France.

Reprints and Correspondence: Bertrand Mathon, MD, MSc, Department of Neurosurgery, La Pitié-Salpêtrière University Hospital, 47-83, boulevard de l'Hôpital, 75651 Paris Cedex 13, France. Tel: +33 (0)1 848273 63; e-mail: bertrand.mathon@aphp.fr ORCID: 0000-0002-9182-5846

\section{KEYWORDS}

Brain biopsy

Complication

Frame-based

Brain tumor

Approach

Trajectory

Mortality 
We read with great interest the article by Jaradat et al, entitled "Stereotactic biopsies of brainstem lesions: which approach?" [4]. We commend the authors for sharing their valuable experience on stereotactic biopsies of brainstem lesions. In this retrospective, single-center cohort on 23 adult patients, the authors report a high diagnostic yield (91\%) and a low rate of complications (no mortality, $13 \%$ of transient neurological morbidity), and discuss the best approach to target brainstem lesions. They recommend a supratentorial transfrontal approach for midbrain lesions, a transcerebellar-transpeduncular route for pontine lesions and for the lesions located in the upper part of the medulla oblongata, and a transfrontal trajectory for the other medullary lesions.

Based on our experience and findings [7, 11], we would like to offer our view and contribution to the field of brainstem biopsies. In a previous study on 1,500 consecutive stereotactic biopsies, we highlighted that brainstem biopsy-targeted lesions was independent predictor of biopsy-related mortality [11]. In the case series from Cheng [3] and Quick-Weller [9], the mortality rates related to brainstem biopsies were also higher than for other targets (2.7\% and $3.8 \%$, respectively). As a structure associated with critical functions, biopsies targeting the brainstem may be associated with more functional and even fatal complications [10].

Between April 2009 and October 2020, 50 patients underwent frame-based stereotactic brainstem biopsy at our institution. In this series, $2 \%$ of brainstem biopsies were followed by a permanent neurological worsening and $6 \%$ of biopsies were fatal. After multivariate analysis, the use of a supratentorial transfrontal approach was the only predictor of post-biopsy symptomatic complications (OR $0.1,95 \% \mathrm{Cl}(0.02-0.9), \mathrm{P}=0.04)$. In the light of these findings, we suggest using the transcerebellar-transpeduncular trajectory whenever practicable. The transfrontal approach is indicated for midbrain lesions. Concerning the lesions located within the lower part of the medulla oblongata, they can be reached either using a stereotactic transfrontal approach or an infracerebellar open route [12].

Regardless the approach, and more than for any other biopsy target, the number of collected tissue samples must be limited, due to the associated risk of bleeding and neurological injury. Thus, the use of fluorescent agents (e.g., 5-ALA), especially for high-grade glioma[ 8] and lymphoma [5] patients, may obviate the need for higher numbers of specimens during stereotactic biopsy for diagnosis which may lessen post-biopsy complication rates. In addition, the use of molecular markers [1] and intraoperative diagnostic evaluation using frozen section or smear [6] may also avoid taking too many tissue samples and carrying out a second biopsy in case of initial negativity. 


\section{Conflicts of interest}

The authors declare no conflicts of interest.

\section{Funding}

There is no funding source for this study.

\section{Ethics and patient consent}

As for all observational studies of routinely acquired data, a waiver for written informed consent was obtained. 


\section{REFERENCES}

1. Barritault M, Picart T, Poncet D, et al (2020) Avoiding New Biopsies by Identification of IDH1 and TERT Promoter Mutation in Nondiagnostic Biopsies From Glioma Patients. Neurosurgery 87(4):E513-E519

2. Chabaane M, Amelot A, Riche M, Bielle F, Mokhtari K, Carpentier A, Touat M, Mathon B (2020) Efficacy of a Second Brain Biopsy for Intracranial Lesions after Initial Negativity. J Clin Neurol 16(4):659-667

3. Cheng G, Yu X, Zhao H, Cao W, Li H, Li Q, Li Z, Yin F, Liu R, Zhang J (2020) Complications of stereotactic biopsy of lesions in the sellar region, pineal gland, and brainstem: $A$ retrospective, single-center study. Medicine (Baltimore) 99(8):e18572

4. Jaradat A, Nowacki A, Fichtner J, Schlaeppi J-A, Pollo C (2021) Stereotactic biopsies of brainstem lesions: which approach? Acta Neurochir. doi: 10.1007/s00701-021-04733-2

5. Kiesel B, Millesi M, Woehrer A, et al (2018) 5-ALA-induced fluorescence as a marker for diagnostic tissue in stereotactic biopsies of intracranial lymphomas: experience in 41 patients. Neurosurg Focus 44(6):E7

6. Mathon B, Amelot A, Mokhtari K, Bielle F (2019) Increasing the diagnostic yield of stereotactic brain biopsy using intraoperative histological smear. Clin Neurol Neurosurg 186:105544

7. Mathon B, Le Joncour A, Bielle F, et al (2020) Neurological diseases of unknown etiology: Brain-biopsy diagnostic yields and safety. Eur J Intern Med 80:78-85

8. Millesi M, Kiesel B, Wöhrer A, Mercea PA, Bissolo M, Roetzer T, Wolfsberger S, Furtner J, Knosp E, Widhalm G (2020) Is Intraoperative Pathology Needed if 5-AminolevulinicAcid-Induced Tissue Fluorescence Is Found in Stereotactic Brain Tumor Biopsy? Neurosurgery 86(3):366-373

9. Quick-Weller J, Lescher S, Bruder M, Dinc N, Behmanesh B, Seifert V, Weise L, Marquardt $G$ (2016) Stereotactic biopsy of brainstem lesions: 21 years experiences of a single center. J Neurooncol 129(2):243-250

10. Riche M, Amelot A, Peyre M, Capelle L, Carpentier A, Mathon B (2021) Complications after frame-based stereotactic brain biopsy: a systematic review. Neurosurg Rev 44(1):301-307

11. Riche M, Marijon P, Amelot A, Bielle F, Mokhtari K, Pineton de Chambrun M, Mathon B (2021) Severity, timeline and management of complications after stereotactic brain biopsy. J Neurosurg

12. Schlaeppi J-A, Andereggen L, Nowacki A, Pollo C (2020) Stereotactic posterior midline approach under direct microscopic view for biopsy of medulla oblongata tumors: technical considerations. Acta Neurochir (Wien). doi: 10.1007/s00701-020-04600-6 